at key points in the trade, including places where parrots are currently sold openly in large urban centres and at international borders, including the airports through which parrots enter international markets (Global Ecology and Conservation, 2018, 16, e00429).

IFEANYI M. EZENWA and CHRISTOPHER NWANI Department of Zoology and Environmental Biology, University of Nigeria Nsukka, Nsukka, Enugu State, Nigeria

E-mail ifeanyi.ezenwa@unn.edu.ng

UlF OtTosson A. P. Leventis Ornithological Research Institute, University of Jos Biological Conservatory, Jos, Nigeria

RowAN O. MARTIN World Parrot Trust Africa Conservation Programme, Hayle, UK, and FitzPatrick Institute of African Ornithology, University of Cape Town, South Africa

\section{Tricks of the trade-legal trade used to conceal Endangered African grey parrots on commercial flights}

Wild parrots are exported in large numbers from Africa, both legally and illegally, and the region accounts for a large proportion of global trade in all wild birds listed on the CITES Appendices. In the last decade three of the top four most traded birds were African parrot species, and reported exports of wild parrots from Africa during this time totalled 311,439 (Ostrich, 2018, 89, 139-143). In 2016 concerns over the impact of trade on wild populations led to the transfer of the grey parrot Psittacus erithacus, categorized as Endangered on the IUCN Red List, to CITES Appendix I.

Recent investigations into the trade in grey parrots have provided opportunities to observe how criminal actors exploit legal trade in parrots to traffic threatened and protected wildlife. In September 2018 an employee of a wildlife exporter based in the Democratic Republic of Congo (DRC) explained to investigators working for World Animal Protection how grey parrots are concealed within legal shipments of so-called green parrots. In the same month, monitoring by the World Parrot Trust of trade in parrots via social media revealed a shipment of grey parrots mixed with red-fronted parrots Poicephalus gulielmi. The shipment that originated in DRC was intercepted by customs on arrival in Kuwait and was accompanied by paperwork for other species. The parrots travelled on a flight operated by Turkish Airlines via Istanbul, a route identified as commonly used in the transport of wild parrots from Africa (Global Ecology and Conservation, 2018, 16, eoo429). In 2018 DRC established an annual export quota of 2,500 red-fronted parrots, which are locally referred to as 'green parrots'. Exports of red-fronted parrots from DRC have risen five-fold since grey parrots were transferred to Appendix I of CITES (mean exports during 2017-2018 compared with mean exports during 2012-2016; CITES trade statistics derived from the CITES Trade Database on 19 December 2018) and this increase may in part reflect an increase in the fraudulent use of permits to traffic grey parrots.

Furthermore, there is evidence that the legal parrot trade is being used as cover for the illicit trade in other wildlife, including threatened primates. An investigation led by the BBC into the trafficking of chimpanzees Pan troglodytes from West Africa led to the seizure of a legal shipment of parrots entering Nepal in which two young chimpanzees were found concealed in a hidden compartment (Nepal busts chimp smugglers after investigation, 10 October 2018, bbc.co.uk/news/world-asia-45808743). This shipment also travelled on a flight operated by Turkish Airlines via Istanbul. Monitoring of trade via social media (Global Ecology and Conservation, 2018, 16, e00429) has revealed further instances in which individuals trading in wild parrots also traded in other species. A Pakistan-based wildlife trader, for example, who on multiple occasions advertised grey parrots imported from Africa, as recently as December 2018 advertised specimens of several species of primates endemic to West and Central Africa. In September 2018 investigators working for World Animal Protection observed a bonobo Pan paniscus at a parrot holding facility in DRC.

Customs authorities and other enforcement agencies need to be vigilant to the risks posed by criminal actors misusing the legal trade and ensure that shipments of parrots originating in Africa are adequately inspected and are accompanied by the correct documentation. Carriers of shipments of parrots, primarily airlines, have a critical role to play by ensuring staff are adequately trained and that systems are in place for rapidly disseminating information on illegal activity to enforcement agencies. Immediate action in these areas would help airlines meet recent commitments made as signatories to the United for Wildlife Transport Taskforce Buckingham Palace Declaration to shut down the air transport routes exploited by wildlife traffickers.

Rowan O. Martin ${ }^{*}$ and CRISTIANa SENNI World Parrot Trust, Hayle, UK. E-mail rmartin@parrots.org

NeIL D'CRUZE† and NICK BRUSCHI World Animal Protection, London, UK

${ }^{*}$ Also at: Fitzpatrick Institute of African Ornithology, University of Cape Town, South Africa

†Also at: Wildlife Conservation Research Unit, Department of Zoology, University of Oxford, Oxford, UK 